Watson, Nick J. and O'Keefe, Catherine

A. (2014) "Celebration" as the Spiritual Expression of Leisure and Sport: Reflections on the L'Arche Tradition and the Special Olympics. Journal of Disability \& Religion, 18 (1). pp. 64-81.

Downloaded from: http://ray.yorksj.ac.uk/id/eprint/835/

The version presented here may differ from the published version or version of record. If you intend to cite from the work you are advised to consult the publisher's version: http://dx.doi.org/10.1080/15228967.2014.868992

Research at York St John (RaY) is an institutional repository. It supports the principles of open access by making the research outputs of the University available in digital form. Copyright of the items stored in RaY reside with the authors and/or other copyright owners. Users may access full text items free of charge, and may download a copy for private study or non-commercial research. For further reuse terms, see licence terms governing individual outputs. Institutional Repository Policy Statement

\title{
RaY
}

Research at the University of York St John

For more information please contact RaY at ray@yorksj.ac.uk 
Running Head: 'Celebration’ as the Spiritual Expression ...

\section{'Celebration' as the Spiritual Expression of Leisure and Sport: Reflections on the L'Arche Tradition and the Special Olympics}

JRDH Special Edition (Sports, Religion and Disability), 18.02

Nick J. Watson (first named author)

Senior Lecturer, Sport, Culture and Religion

Faculty of Health and Life Sciences

York St John University

Lord Mayor's Walk

York, Y031 7EX

England

E-mail address: n.watson@yorksj.ac.uk

Catherine A. O’Keefe, M.Ed. (first-named author)

Senior Instructor, Leisure Studies and Therapeutic Recreation

Faculty of the Department of Health, Physical Education, and Leisure Studies

University of South Alabama

171 Jaguar Drive, HPE 1037

Mobile, AL 36688

USA

E-mail address: cokeefe@southalabama.edu

Citation: Watson, N.J. and O’Keefe, K. (2014) 'Celebration' as the Spiritual Expression of Leisure and Sport: Reflections on the L'Arche Tradition and the Special Olympics, Journal of Religion and Disability, 18(1): 64-81. See:

http://www.tandfonline.com/doi/full/10.1080/15228967.2014.868992\#.UxXySFRFDcs 


\begin{abstract}
The provision of leisure and sport for persons with disabilities is an integral part of the United Nations Convention on the Rights of Persons with Disabilities (2006, article 30), and in turn, these activities can positively contribute to the physical, emotional and spiritual lives of those with physical and/or intellectual disabilities (Heintzman, 2014; Patterson \& Pegg, 2009). Based on this premise, we argue that the activities of leisure and sport (esp. the Special Olympics) offer those with disabilities in L’Arche communities — an international federation of communities founded in the mid-1960s by the French Canadian, Jean Vanier-a vehicle for spiritual expression through 'celebration'. By way of interdisciplinary discussion, we explore the diverse and rich meanings of celebration within the context of leisure and sport, with specific reference to embodied experiences, such as fun, joy, belonging, festivity, laughter and play, as understood in the writings of the founder of L'Arche, Jean Vanier, the catholic philosopher, Joseph Pieper, and scholars from a range of disciplines. In conclusion, we suggest that the experience of celebration through leisure and sport participation (especially via the Special Olympics) is an invaluable and understated source of meaning and hope for those with disabilities within L’Arche communities, and beyond.
\end{abstract}

KEY WORDS Celebration; leisure; L’Arche; sport; play; joy; Special Olympics INTRODUCTION 
The rich vein of scholarship that examined ideas of 'virtue' and the 'good life' in Greek philosophy, for example, in the writings of Aristotle (384-322 BC), has provided contemporary leisure theorists and philosophers of sport a foundation to examine organizations, such as L'Arche (1964-) and the Special Olympics (1968-), that have emerged during the last 50 years. It has also helped tackle the global challenge of blending diverse social groups, in ways that might bring out the very best in the human quest for cultural and spiritual expression, both individually, and collectively. This is perhaps best exemplified in the philosophies that underpin two organizations that have many similarities with regard to championing the cause of those with intellectual disabilities: (i) L'Arche, an international catholic federation of over 150 communities (in 40 countries) that was founded by the French-Canadian, Jean Vanier (1928 -), where individuals with intellectual disabilities ('core members') live in community and 'mutual relationships' with personal 'assistants'. Leisure (and sport to a lesser degree) is one dimension of community life, and (ii) the Special Olympics that was founded in Chicago in 1968 and is the world's largest organization for those with intellectual disabilities, serving over 4 million athletes through 52,000 Olympic-type events every year (Shriver, 2014). According to L’Arche International (2013), the goals of L'Arche are:

- to make known the gifts of people with intellectual disabilities (or learning disabilities as they are known in the UK)

- to foster the development of communities that respond to members' changing needs

- to engage with local cultures while working toward a more human society. 
The goals of the Special Olympics (2013) are captured in the organization's own Mission Statement:

The mission of Special Olympics is to provide year-round sports training and athletic competition in a variety of Olympic-type sports for children and adults with intellectual disabilities, giving them continuing opportunities to develop physical fitness, demonstrate courage, experience joy and participate in a sharing of gifts, skills and friendship with their families, other Special Olympics athletes and the community.

In addition to the similarities which are evident in the vision and goals of L'Arche and the Special Olympics, we argue that there are three other reasons for examining the diverse and rich meanings of 'celebration' through leisure and sport in these modern movements and the numerous related embodied experiences that flow from celebratory activities, such as fun, joy, belonging, festivity, laughter and play. First, Jean Vanier the pioneering founder of L'Arche, has, over the years, made a number of explicit connections to the Special Olympics in his writings, for example:

There is a beautiful story of a young man with a disability who wanted to win the Special Olympics; he got to the hundred meter race and was running like crazy to get the gold medal. One of the others running with him slipped and fell; he turned round and picked him up and they ran across the finishing line together last. Are we prepared to sacrifice the prize for solidarity? It's a big question. Do we want 
to be in solidarity with others? ... We have to look at the poorest and the weakest. They have a message to give us. (Vanier cited in Whitney-Brown, 2008, pp. 167168)

Second, the CEO of the Special Olympics since 1996, Timothy Shriver (2014, p. 213), recently noted the spiritual essence of the movement, by calling for a 'dignity revolution' that acknowledges the sacredness and beauty of persons with intellectual disabilities, that will result in an 'end [to] the scourge of discrimination'. He states that:

In the Special Olympics movement, we aim to cultivate that eye of love every day. While we have no faith based convictions and no religious affiliations, we nonetheless follow in the footsteps of prophets and leaders who teach the eye of love. We follow Isaiah who exhorted his readers to care and service with the promise that in healing divisions, darkness would become like noonday. We follow Jesus who rejected all hierarchies of power and value and invited his followers to 'love one another. . .

Clearly, there is a spiritual undercurrent that drives the Special Olympics and the heartfelt vision of its Executive leadership team, which has also been highlighted in recent Christian theological analyses of the movement; some of which explicitly discuss the varying similarities with the ethos and practices of L'Arche (Yong, 2014; Watson 2013, 2102; Brock, 2012; Shafer, 2012: 189-196). The third and final reason that we suggest it is fruitful to explore the underpinning philosophies of both organizations, is that recent 
empirical research has demonstrated that some 'core members' (those persons with intellectual disabilities) of L'Arche communities, also participate in Special Olympic events (Watson \& Parker, 2012). While identifying commonalities in the vision and goals of L’Arche communities and the Special Olympics (and acknowledging the many differences), the principle focus of our essay is to explore the role of 'celebration' as a means of spiritual expression through leisure activities and sport for those with intellectual disabilities living within in these two settings. Our discussion focuses more on L'Arche and its underpinning philosophy of celebration, due to its explicit spiritual foundation, while also making clear links to the Special Olympics, a movement which, we argue, that has a 'vision' with a pervasive spiritual 'undercurrent'.

In accounting for 'reflexivity', that is, the interactions and relationship between the 'author(s), text and readers' (Flick, 2009: 422), the content our discussion has emerged from both our scholarly activities in the field of disability studies and practical engagement in L'Arche communities: the second author (O’Keefe) having been involved in a L'Arche community in North America for over 30 years (O’Keefe, 1994/2006) and the first author (Watson) having undertaken ethnographic research in a L'Arche community in the UK (Watson \& Parker, 2012) and having worked as a disability sport leader. It is hoped that these collective experiences provide a 'practical assessment' of the topic that is informed by research.

The essay is structured around four themed sections: (i) a brief history of L'Arche and its founder, Jean Vanier, to provide a socio-historical context for what follows (ii) reflection on the spiritual roots of leisure, play and sport (iii) a historical account that illustrates how notions of festivity, laughter and religious rituals inform modern 
understandings of celebration, and (iv) an analysis of ‘celebration' as spiritual expression in the modern context of L'Arche communities and the Special Olympics movement.

\section{JEAN VANIER AND L’ARCHE: A BRIEF HISTORY}

The spiritual and social experiment that is L'Arche began in 1964 and was founded by the Canadian, Jean Vanier, son of Georges Vanier, the former Governor General of Canada. Vanier's journey from training as a naval officer to completing a PhD. in the study of Aristotle's ethics (and importantly here, the concept of friendship) allowed him to experience both the practical world of military leadership and the esoteric world of classical ideas. Exposed to the sight of Jews returning from concentration camps at the end of World War II, aware of the struggles of the poor through his religious upbringing, and influenced by the devastation wrought by atomic warfare, Vanier decided, while on military leave for a spiritual retreat, to abandon his military career and follow a path into monastic life, seeking spiritual growth through contemplation. Vanier wrote that "prayer is a place of rest and quiet. When we love someone, don't we delight in being with each other?” (Spink, 2006, p. 31). Vanier’s desire to deepen his relationship God and to love others completely, eventually led him to consider another option. He resigned his military commission in 1950 as the influence of spiritual contemplatives and activists, such as Thomas Merton and Catherine Dougherty led him to take the internal journey emphasized by Plato and the outward path described in the rationalistic philosophy of Aristotle, combining the two in the light of his Christian faith (Spink, 2006).

In France, under the spiritual direction of Father Thomas Phillippe, a Dominican priest, Vanier began to examine the meaning of the Gospel of John which focuses on the 
concept of 'remaining,' from the Greek menein, which means to abide or dwell (Spink, 2006). The writer of the gospel emphasizes the value of dwelling with God in the deepest of friendships and then extending that invitation to others, creating an image of dwelling not just with others, but within one another. This kind of thinking later helped Vanier conceptualize the value of living in community when Father Phillippe suggested that Vanier's true vocation might lie in a new direction, as a layman experiencing a deeper kind of friendship with those most rejected by society, the poor and, in particular, those with intellectual impairments.

During this period of transition, it is possible that Vanier would have been aware of Aristotle's concept of leisure (due to his doctoral work on Aristotle) and its great value in defining what work should offer - the opportunity to delve into the spiritual realm and all that doing so yields, in terms of truth and goodness. There is no evidence, however, that he consciously made this connection when he agreed, with Father Thomas' encouragement, to take two men from an institution in the small village of Trosly Breuil, France, to live with him. If anything, life with persons who are intellectually impaired would seem to remove one further and further from the ideas of philosophy and the insights of great thinkers. As the journey developed for this new community, called L'Arche (with reference to the Biblical Ark as a place of refuge), it became apparent that the scriptural text from the gospel of Luke (10:21) was indeed applicable. In this passage, Jesus thanks God for hiding truths from the learned and the clever and revealing them to mere children. One of the great paradoxes of Vanier's life is that his original quest for truth through the intellectual life eventually led him to experience it with those who appeared less capable of intellectual understanding. As Comensoli (2011) suggests, 
Vanier’s path was one of 'descending the ladder', with Vanier noting that “The Holy Spirit created L'Arche through Father Thomas Phillippe to reveal to an age obsessed with achievement that the essential value of each person lies, not in intelligence, but in the heart” (Vanier, 1995, p. 10).

To some degree, Vanier’s work resonates with that of Joseph Pieper's (19041997), a German catholic philosopher, who wrote about the effortless spirit required to engage in leisure. Vanier and Pieper shared the same Catholic heritage that informed their intellectual pursuits. Pieper (1948/1998) wrote at the end of World War II that leisure is an attitude of contemplative celebration, a stillness that dances. He went on to state that leisure “ $\ldots$ is not the same thing as quiet, or even an inner quiet. It is rather like the stillness in the conversation of lovers, which is fed by their oneness” (p. 33). For many in L'Arche, relationships involve this kind of stillness because a significant number of community members who have disabilities are unable to speak or are very limited in verbal skills. Only by trial and error in the early history of L'Arche did Vanier and his friends learn how to harness this gift of stillness. Paradoxically, it became a source of enormous creativity and playfulness springing forth in 'celebration', something that catholic philosopher, Joseph Pieper, addressed at length.

\section{THE SPIRITUAL ROOTS OF LEISURE, PLAY (AND SPORT)}

The $20^{\text {th }}$ century found a great defender of the value of leisure in Josef Pieper, who, after World War II, wrote what has become a classic text for spiritually-minded leisure and sport theorists, Leisure: The Basis of Culture (1948/1998). Pieper's philosophy was heavily informed by his Catholic theology that was rooted in the work of Thomas Aquinas (c. 1225-1274), and thus, Aristotle. The central thesis of his 
groundbreaking text, is a critique of the 'cult of work' that had come to characterize western industrialized nations and in response to this, Pieper proposed a need for a renaissance of a classical understanding of leisure and the related embodied experiences of play and celebration. In short, Pieper made the connection between spirituality and leisure, seeing the two as intrinsically intertwined, as have catholic theologians (drawing heavily on Pieper) when analyzing various forms of modern sporting experience (e.g., Lixey et al., 2012). Pieper identified leisure, in the classical understanding of the term, as a spiritual endeavor which is accessible to all, because the knowledge required to engage in it, is '.. that simple knowing which takes place in higher natures, and thus we can conclude that human beings possess a power of intellectual vision' (Pieper, 1948/1998, p. 12). Further, this kind of intellectual and embodied activity is not 'work' but that which is best acquired without effort through various modes of leisure.

Pieper's reflections on leisure (and sport) were birthed from his witness of the xenophobia that was fanned by political opportunists who, with Hitler, sought to purify the German population and establish what they perceived to be the 'ideal culture'. Pieper and his contemporary, the Dutch cultural historian, Johan Huizinga (1950), who wrote a seminal book on the history and value of 'play', formed their perspectives against the collapse of Nazi Germany’s Third Reich, a government that ranks among the most treacherous in human history. They championed the idea that artifacts of culture demonstrate that leisure can either contribute to the spirit of community or help destroy it. In so doing, scholars such as Pieper and Huizinga gave leisure (and sport) its' cultural currency, showing that it could offer a lived awareness of the 'good life', in direct contrast to the philosophy of Nazism. Huizinga (1950) was of the opinion that play had a 
sacred, festive and celebratory dimension that could assist in contributing to the 'spirit of community' and the 'good life', not unlike, Pieper’s (1948/1998) offerings towards the spiritual significance of leisure:

We may well call play a "totality" in the modern sense of the word ... In all its higher forms [play] at any rate belongs to the sphere of festival and ritual—the sacred sphere ... The Platonic identification of play and holiness does not defile the latter by calling it play, rather it exalts the concept of play to the highest regions of the spirit ... In play we move below the level of the serious, as the child does; but we can also move above it—in the realm of the beautiful and sacred. (cited in Mathisen, 2005, p. 281).

Huizinga’s (1950) highly influential work on human play has informed the subsequent scholarship of theologians (e.g., Moltmann 1972; Johnston, 1983) and sport and leisure theorists (e.g., Thoennes, 2008). In a recent 'review' of the corpus of publications that addresses the theology and philosophy of play, play is characterized by: "a sense of freedom and autonomy, a non-utilitarian ethic, a celebratory and spontaneous spirit, creativity, joy, intrinsic enjoyment (the autotelic), a transcendence of egoboundaries and a feeling of psychic (and spiritual) holistic integration” (Watson \& Parker, 2013, p. 16). The presence of these attributes in individual and communal experience of leisure pursuits, for example art, music, literature, drama, dance, sport, dress, ritual, cuisine, and architecture, could be seen as a positive force, as it was in ancient Greece, for honoring the collective human spirit and the creative individual 
expression in modern organizations, such as the network of L'Arche communities and the movement of the Special Olympics. Before specifically examining the notion of celebration in these contexts, we first provide a brief historical account of the related concept of 'festivity'. We argue that understanding this connection between celebration and festivity is important, in that historically, festivity is intimately related to religious celebratory rituals and activities and the consequential human emotions and states, such as laughter and humor, foolishness, freedom, playfulness and spirituality.

FESTIVITY AND LAUGHTER: MAINSTAYS OF L’ARCHE AND THE SPECIAL

\section{OLYMPICS}

Nearly two decades after the publication of his seminal monograph on leisure, Joseph Pieper provided a historical analysis of the popularity and cultural relevance of 'festivity' in western civilization (e.g., during the Medieval period), In Tune with the World: A Theory of Festivity (1965), which was essentially mirrored in Harvey Cox's well-known theological work, Feast of Fools (1969). Importantly, both Pieper and Cox demonstrate how the loss of festivity during modernity is, at least in part, a reason for the decline in celebration, joy, laughter and the 'spirit of play' in modern-day life. Recently, the philosopher of sport, Eichberg (2009a, p. 217; also see Luo, 2010), in reflecting on the historical decline of religious festivity in sport and wider culture (and thus spiritually rooted celebration), has noted that:

Festivity was replaced by specialized work - the work of achievement, the work of health and educational work. With the genesis of industrial society, the relations between sport, folk culture and festivity changed fundamentally. The 
laughter of festivity and the fool of carnival disappeared from the world of sports . .. and Pierre de Coubertin developed a new-religious vision for festival of the modern Olympics.

Within the context of the present discussion, it is interesting that Eichberg (2009a, p. 218) goes onto to explain that 'festivity' is a crucial cultural element in making “... connections between disabled and able-bodied ... and encounters with ethnic groups". Indeed, we argue that the atmosphere of festivity, as demonstrated in L'Arche (Vanier, 1995), allows for freedom of celebration, spiritual expression and a sense of 'true belonging' (Swinton, 2012), sometimes mediated through leisure and sport activities (O’Keefe, 1994/2006). Inseparable from experiences of festivity throughout history, are those of is laughter and humor, life enriching elements that have long been recognized as social and communal virtues. This is a topic that has received relatively limited attention across the academic disciplines, while recently there has been a number of notable contributions from theologians (Capps, 2006), sociologists of religion (Berger, 1997), and scholars reflecting on sport (Aggerholm \& Ronglan, 2012; Eichberg, 2009b; Walford, 2009; Heddendorf, 1994/2006).

In an essay on the phenomenology of 'laughter' in sport and leisure locales, Eichberg (2009b, p. 286) identifies the "philosophy of perfectionism" and the "seriousness of modern sport", as the principle reason for the loss of a culture of laughter and the capacity to celebrate one’s humanity and faith. Paradoxically, O’Keefe (2006, p. 113) comments that in L'Arche communities, leisure (and sporting activities) can be used to foster a celebratory and festive spirit and that "the Christian focus of love in L'Arche is 
to announce the ridiculous - that we NEED them ['core members'] to teach us to trust, laugh easily, live more in the moment, enjoy the presence of others, and accept one another unconditionally”. Of course, sharing and celebrating life and the importance of relationships is at the heart of the L'Arche sub-culture, which maps very closely on to the findings of a number of empirical research studies of the Special Olympics, which demonstrate that: “... the motives for participation and long-term adherence [in the Special Olympics], show that although external rewards are of some importance (e.g., medals, winning and the perception of others), the intrinsic motives of fun, friendship and relationships are by far the most important reasons” (Watson 2013, p. 168; also see, Shriver, 2014; Siperstein, Kersh \& Bardon, 2007).

These sentiments are also articulated in Wellard's (2014) recent social-scientific text, Sport, Fun and Enjoyment: An Embodied Approach. Following Pieper (1948/1998) and Huizinga (1950), here Wellard laments the loss of playfulness and childlikeness in the 'work-like' character of much of organized children and youth sports, something that is largely rooted in the 'Protestant work-ethic' that has characterized the development and philosophy of many modern western societal institutions (Overman, 2011; Guttman, 1978/2004; Weber, 1958).

In one chapter, Wellard (2014) explores the 'significance of social embodied pleasure’ for the 'non-sporty' and, in particular, the sense of belonging that disabled youngsters might experience when participating in disability sport. One young girl, in responding to an interview question posed by the author, as to the significance of the potential loss of provision of disability sport in her community, comments that, "it's not so much the boccia [an adapted bowling game]; people would lose friendships, and a 
place to meet” (Wellard, 2014, p. 70). Indeed, as with the undergirding philosophies of L'Arche and the Special Olympics, it is, as Wellard (2014: 20) concludes, the “ontological aspects of 'being' in the context of sport and physical activities” that are vital. The fun, the physical pleasure, joy and sense of belonging experienced (see Null, 2004), or, in the language of L'Arche or the Special Olympics, the 'being with others (presence)' and the extravagant celebration of individuals' gifts, regardless of their abilities or disabilities.

Unfortunately, though, as Eichberg (2009b, p. 292, 300) concludes in his analysis of laughter in sporting and leisure settings, in the modern sports paradigm, "Laughter has gone Underground” but “... laughter was and is a part of social wealth within its culture. It is not only order and perfection that creates cultural richness, it is also the disorder of the imperfect human being that implies human qualities. Laughter has a quality which is related to factal chaos”. Any person who has spent any time in a L'Arche community knows full well that 'chaos', 'belly laughter', ‘crying’ and human 'imperfection' and 'brokenness', certainly not 'perfectionism' and 'order', are its defining characteristics. This fact is the very reason that the organization's founder, Jean Vanier, and numerous others, hold L'Arche to be an 'embodied prophetic' organization (e.g., Harshaw, 2010; Hauerwas \& Vanier, 2009). Similarly, the CEO of the Special Olympics, Timothy Shriver (2014, p. tbc) welcomes “... the challenge of ushering in a new era of celebration of the gifts of people with intellectual disabilities ... ." that “ ... will shame the powerful with their wisdom and silence the wise spirit” (also see, Yong, 2014; Watson 2013, 2012; Brock, 2012). In short, we propose that both L'Arche and the Special Olympics may act 
as a foil from a God (towards modern secular culture) who is characterized by, and seeks in his creatures, humility, vulnerability, relatedness, love and acceptance for all.

Today we witness radical differences and levels of acceptance, among ethnic, racial, religious, and/or social groups, whose cultures may seem mutually exclusive. On any given day one may witness the results of those tensions in media reports where political pressure is brought to bear on societies to either impose a dominant cultural ideology, or maintain a pluralistic balance of practices that are mutually respectful. We suggest that it behooves us to look around for examples of cultural behaviors that capture the essence of spirituality, celebration and leisure, while honoring differences within and among communities.

Of all the places that one may look for such an example, it seems paradoxical that it could lie among the most marginalized and overlooked. How odd that a very powerful model of leisure and spirituality exists in communities formed around persons who, for most of history, have been discarded, abandoned, or institutionalized and, in Nazi Germany, targeted for extinction. What would communities of individuals with profound intellectual disabilities, such as those found in L’Arche and the Special Olympics, possibly have to reveal about cultivating more satisfying lives? In the next section we analyze ways in which the experience of 'celebration' in an atmosphere of festivity, laughter and playfulness, have become a central characteristic of the modern movements of L'Arche and the Special Olympics.

‘CELEBRATION’ AS SPIRITUAL EXPRESSION IN L’ARCHE (AND THE SPECIAL OLYMPICS) 
In Reimer's (2009, p. 126) ethnographic study of a number American L'Arche communities, he observes that " $\mathrm{L}$ 'Arche is an incubator for loving character, celebrating life in the midst of disability”. Similarly, the CEO of the Special Olympics, Timothy Shriver (2014, p. tbc) comments that the “... Special Olympics movement is a challenge to the world to recognize human giftedness, dignity and value”, it is “...a celebration of the gifts of people with intellectual disabilities”. According to the Oxford English Dictionary (2013), celebration derives from the Latin celebrare, and means:

... the performance of a solemn ceremony; spec. the action of celebrating the eucharist ... The observing of a feast, day, or special season ... The honouring or recognizing of an event by religious ceremonies, festivities ... Making famous, publicly praising, extolling ...'?

Celebrating and honoring others is an action and good of the human spirit. To engender celebration and honoring of others, through enjoyable activity, like leisure and sport, is a concept that is shared across cultures and societies, even if the expressions are unique from culture to culture. As we have noted above, the association of celebration with religious expression, festivity and play, is embedded in cultural history and it heightens our awareness of something sacred and calls us to respond. Our responses may be spontaneous, playful, and unrehearsed or highly ritualized over time. In either case, celebration is a human expression about something we revere.

In the case of L'Arche and the Special Olympics, what is celebrated most is the dignity of every human person no matter how able or disabled. Historically, the treatment 
of persons with disabilities has often been impersonal, if not cruel, and it has not been uncommon for records of birthdays, or other significant life experiences, to be undocumented (Whitney-Brown, 2008). What Vanier recognized, was that affirming each person's uniqueness starts with an affirmation of his/her very existence. Birthday celebrations honored the value of each person's life, and anniversaries that marked one's coming to L'Arche validated each core member as a vital part of the community (Reimer, 2009, Ch. 6). Over decades of affiliation with L'Arche, core members find and develop meaningful roles in each home. They 'parent' each other at times, offer the deepest consolation of friendship, and challenge each other to grow. The term L'Arche has used to describe those who commit to sharing their lives with the core members, is, 'assistant'. And so, together, each home is a family of core members and assistants and some L'Arche communities are large enough to have several homes with a community workshop for daily activities. A participant in Reimer's (2009, p. 145) study who is a L'Arche 'assistant' further emphasizes the role of celebration for all those living in these communities, in stating that 'L'Arche is a place of celebration. [smiling broadly] We love to celebrate... People want to celebrate with you and you need to allow yourself to celebrate”.

L'Arche's foundation in France and its expansion into other European countries has naturally engendered an involvement with traditions related to those countries. Festivals are a part of those traditions and the leisure and sporting activities that are an inherent aspect of them. Pieper (1965; 1948/1998) looked to the work of Karl Kerenyi, a historian of religion, for the purpose and meaning of festivals. He noted that festivals give affirmation to God's creation and allow us to integrate "peace, intensity of life, and 
contemplation all at once” (Pieper, 1948/1998, p. 33). Every action that elevates the ordinary to the realm of the festive is an opportunity for members of L'Arche to affirm the value of core members' and assistants' both individually and collectively. Every person is seen as a gift to the larger society. The festive action of leisure and sport serve to cement this value as foundational to community life.

Anyone who has lived for a significant time at L’Arche, however, will tell you that it is often difficult. L’Arche is an interesting study in the paradox of living a celebratory life, constructing festivals amidst the everyday activities of caring for persons with disabilities and sharing their lives. Experience in a L'Arche home can be highly celebratory but at the same time, deeply connected to suffering and human brokenness. The core members have intellectual, emotional, social, and physical problems that can be daunting. Some seem to have had their spirit crushed due to prolonged suffering, abuse, or abandonment. A great deal of the literature written for and about L’Arche communities by its leaders and scholars focuses on anguish, grief, and loss (Reinders, 2010; Reimer, 2009; Nouwen, 1997). For example, accompanying a ‘core member' who may have encountered much suffering, for example, through a broken relationship between a mother and child, involves enormous skill and sensitivity. These are not losses that can easily be remedied. It often takes years of living in L'Arche to create or restore relational trust and confidence, to find one’s gifts, and to become a needed member of a social unit, whether at home, work, or play. The enjoyment associated with leisure and sport allows L’Arche communities to gradually draw a core member out in a non-threatening, playful and celebratory environment where they can be affirmed and valued. Laughter is a key ingredient in this process, a real antidote for the anguished soul. As the title of Shriver's 
(2014) recent essay on the Special Olympics suggests, Triumph over Anguish: The Inspiration of the Special Olympics, which is in itself a clear testament to the potential power of sports and leisure to offer relational healing, joy and life in all its fullness, to those on the margins of society.

Though there are now approximately 150 L'Arche communities around the world, life within them remains relatively simple, due at least in part to the scarcity of economic resources and the complex limitations experienced by the core members. In the early days of L'Arche, simple celebrations were all that these communities could afford. Core members and those without disabilities who lived within them participated in activities together that were available, inexpensive, simple to do, and enjoyable for everyone. Singing, exercising together, making gifts, preparing meals, gardening, and playing games with one another were staples in the social fabric of the homes. These simplistic forms of recreation provided something of a contrast to the great effort required to provide physical care and emotional support for people who had many wounds from institutional living and rejection by their families or society at large. Over time, L'Arche discovered that simple festivities were essential, and for some core members, they experience this through engagement in the Special Olympics (Watson, 2013; Watson \& Parker, 2012). Such experiences are extremely valuable in communities where core members often struggle to master skills that require great effort or complex thinking and it helps that activities often requiring the least effort are accessible, to those that are spontaneous and filled with laughter.

Indeed, Vanier's education in Aristotle’s philosophy of friendship and happiness led him to emphasize the need “... to accompany the poor man to the end of his life but 
also to spend that life with him and see that he was happy” (Spink, 2006, p. 79-80). God, in Vanier's eyes, was at the "heart of every celebration in the eyes and laughter of those who were most fragile and most vulnerable” (Spink, 2006, p. 98). Vanier and all the assistants who have lived with and cared for the core members in L'Arche understand that celebration sometimes even trumps prayer as a source of unity within and among all the communities because it expresses a universal language of laughter and joy. Further, Spink (2006, p. 150), quotes Vanier’s recollection that: “... we danced. Seeing all these disabled people dancing, and us dancing, one realized somehow what Heaven should be, that we should all be set free to dance together. Whether we were disabled or not, clumsy or graceful, somehow doesn't matter”. The beauty, creativity, freedom and spiritual nature of 'dance' is something that has been recognized for thousands of years (Savage, 2000), for example, in the rich historical tradition of Jewish festivals. These attributes of dance have also been linked to the aesthetic and artistic dimensions of sporting experience, when played in a 'cooperative spirit', rather than, an 'overly competitive' manner (Watson, 2007).

Since the founding of L'Arche in 1964, an evolution of community growth has occurred. In the early 1970s, when people with disabilities were just emerging from institutional seclusion, and when society was still reticent about accepting them, Jean Vanier formed pilgrimages so that core members and their friends and families, could travel together and socialize on a larger scale (Whitney-Brown, 2008). The small French village of Lourdes was the destination for one of these pilgrimages because of its religious significance as a healing place for the sick and because it could accommodate wheelchairs and those with limited mobility. Vanier believed that everyone should have 
something to look forward to, to engage in enjoyably, and to look back on as a memory. That endeavor is a uniquely human one and even people with limited intellectual abilities appeared to benefit from the anticipation of something different and special, as is the case for many making pilgrimage to a sporting event (Jirásek, 2011), such as, the Special Olympics. The trip itself introduced many to travel for the first time and facilitated the creation of friendships with others who joined them. Then, as now, photographs of celebrations become sacred icons because of their power to make meaning of memories.

Every ten years L'Arche communities gather somewhere in the world to celebrate their mutual commitment, which is very comparable to the communal gatherings of the Deaf Olympics (Haualand, 2007) and the Summer and Winter Games of the Special Olympics which are held in addition to the thousands of regional events that continue year round. The opening event of these L'Arche meetings may take on the feel of the parade of nations at the Olympics (see Luo, 2010), with each community entering the gathering under a banner and wearing specially chosen colors. What is celebrated is not easily seen - that L'Arche (Hauerwas \& Vanier, 2009) and the Special Olympics (Watson 2013, 2012) is a 'prophetic sign' to the world at large, and thus, demonstrates the universal value of sharing life with persons who have been traditionally marginalized. In sharing life and forming homes together in L'Arche, the core members and their friends/assistants cultivate their gifts and help each other, through difficulties and challenges, to live meaningful and happy lives.

A study of leisure preferences in L'Arche in the United States (O’Keefe, 1994/2006), and interviews (conducted by the first author in 2007 and 2012) with international leaders in L'Arche, revealed that leisure, play, and sports are essential 
elements in building community. L'Arche has developed a culture of celebration over its fifty year history that now involves special recognition of birthdays, anniversaries in the L'Arche calendar, religious, ethnic, or national holidays, and the nature of those celebrations keeps the core members at the center of it all. Travel and pilgrimage is often to places where other L'Arche communities can welcome core members easily as guests but may also be to events like the Special Olympics, where L'Arche core members have the opportunity to participate, spectate and compete.

It is in this type of arena that the communities of L'Arche and the Special Olympics, offer something of additional value to the larger society. It is a humble but universal model based on the dignity of every person. It is practical, too, in its insistence that relationships are the vehicle through which we enter the sacred space of others and find a place within the hearts of those who may be very different, sometimes even difficult to reach, often wounded, but always human. Jean Vanier valued the realistic ideals of Aristotle as orderly and sensible, but Aristotle lived in a society that may not have recognized the value of persons with intellectual disabilities. His definition of a human being required rationality. Vanier defined a human being as "someone capable of love” (Spink, 2006, p. 227). This capability includes receiving love, not just merely giving love. The mutuality of a loving human relationship is a mutuality of equal value, not of equal ability.

While we need the ordered and rational approach to life advocated by Aristotle and others, we also need to engage the mystery of the spiritual life, to be open to the possibility that value lies in the intrinsic presence of life, whether plant, animal, or human. Further, the vulnerability of our planet is echoed in the presence of vulnerable 
human beings who live among us. How do we cease treating one another as threats, as foreigners, as strangers or potential enemies? We do so by engaging them as human beings in activities that celebrate both our uniqueness and our similarity. L'Arche took the most marginalized of humans, invited them to enter into relationships with wider society, placed core members at the very center of those relationships, and used celebration as a fundamental vehicle for building community. Those core members of L'Arche, people with a wide range of limitations and gifts, in turn honor us by providing an invitation to be kind. Paradoxically, our response of kindness humanizes us in the process. We also learn how to trust, to be vulnerable, to forgive, to dialogue without words, to embrace diversity, and to love compassionately. And throughout that process, the vehicles of leisure and sport (and art, music, dance, drama, fashion, cuisine, ritual, religion, poetry and literature) is the means by which we can use to elevate the ordinary to the level of the sacred, to deepen our spiritual lives by elevating sublime activity to its rightful place.

\section{CONCLUSION}

After briefly identifying the commonalities in the vision and goals of L'Arche communities and the Special Olympics (and acknowledging the many differences), the main focus of this essay, has been to explore the role of 'celebration' as a means of spiritual expression through leisure activities and sport, for those with intellectual disabilities living in these two settings. We have argued that when the 'festive' and 'celebratory' historical roots of leisure and sport are understood and brought to the fore, then these activities can offer a range of positive embodied experiences for those with intellectual disabilities, such as joy, laughter, a sense of belonging and just plain old fun! 
Based on this premise, we then propose that in accordance with the United Nations Convention on the Rights of Persons with Disabilities (2006, article 30), that more explicit and intentional links should be developed between L'Arche and the Special Olympics movement, so to offer more individuals with intellectual disabilities the enjoyment of leisure and sporting activities in a celebratory environment. In short, to offer those on the margins of society one vehicle to life in all its fullness (John. 10: 10b).

\section{BIOGRAPHICAL NOTE}

Dr Nick J. Watson is Senior Lecturer, Sport, Culture and Religion, Faculty of Health and Life Sciences, York St John University, UK, and associate of the Centre for Sport, Spirituality and Religion, University of Gloucstershire, UK. Catherine A. O’Keefe, M.Ed., is a retired Senior Instructor, Leisure Studies and Therapeutic Recreation, Faculty of the Department of Health, Physical Education, and Leisure Studies, University of South Alabama, US.

\section{REFERENCES}

Aggerholm, K. \& Ronglan, L.T. (2012). Having the Last Laugh: The Value of Humour in Invasion Games. Sport, Ethics and Philosophy, 6(3), 336-352.

Berger, P.L. (1997). Redeeming Laughter: Comic Dimension of Human Experience. Boston, MA, USA: Walter de Gruyter and Co.

Brock, B. (2012). Discipline, Sport, and the Religion of Winners: Paul on Running to Win the Prize, 1 Corinthians 9: 24-27. Studies in Christian Ethics (Sp. Ed. Christian Ethics and Sport), (25)1, 4-19.

Capps, D. (2006). A Time to Laugh: The Religion of Humor. New York, USA: Continuum International Publishing. 
Oxford English Dictionary (2013) Celebration. Retrieved 2 August, 2013, from http://www.oed.com/view/Entry/29415?redirectedFrom=celebration\&

Comensoli, P.A. (2011). Descending the Ladder: The Theological Anthropology of Jean Vanier’s Key Metaphor. Journal of Religion, Disability and Health, 15(2), 115129.

Coreen M. Harada, G.N., Siperstein, R.C., Parker and Lenox, D. (2012). Promoting Social Inclusion for People with Intellectual Disabilities through Sport: Special Olympics International, Global Sport Initiatives and Strategies. In Le Clair, J.M. (ed.), Disability in the Global Sport Arena: A Sporting Chance (pp. 63-80), London: Routledge.

Cox, H. (1969). Feast of Fools. New York: Harper and Row.

Eichberg, H. (2009a). Sport as Festivity: Towards A Phenomenology of the Event. Sport, Ethics and Philosophy, (3)2, 215-236.

Eichberg, H. (2009b). Sport and Laughter: Phenomenology of the Imperfect Human Being. Sport, Ethics and Philosophy, 3(3), 286-304.

Flick, U. (2009). An Introduction: Qualitative Research (4 ${ }^{\text {th }}$ ed.). London: Sage Publications.

Guttman, A. (1978/2004). From Ritual to Record: The Nature of Modern Sports. New York: Columbia University Press.

Harshaw, J.R. (2010). Prophetic Voices, Silent Words: The Prophetic Role of Persons with Profound Intellectual Disabilities in Contemporary Christianity. Practical Theology, 3(3), 311-329. 
Haualand, H. (2007). The Two-Week Village: The Significance of Sacred Occasions for the Deaf Community. In B. Ingstad and S.R. Whyte (eds.), Disability in Local and Global Worlds (pp. 33-55), London: University of California Press.

Hauerwas, S. \& Vanier, J. (2009). Living Gently in a Violent World: The Prophetic Witness of Weakness (Preface, John Swinton). USA: Intervarsity Press.

Heddendorf, R. (1994/2006). From Faith to Fun: Humor as Invisible Religion. In G. Van Andel., P. Heintzman and Visker, T. (eds.), Christianity and Leisure: Issues in a Pluralistic Society (Revised ed.) (pp. 252-262). Sioux Center, IA: Dordt College Press.

Heintzman, P. (2014). Nature-based Recreation, Spirituality and Persons with Disabilities. Journal of Religion Disability and Health, 18(1), pp. tbc.

Huizinga, J. (1950). Homo Ludens: A Study of the Play Element in Culture. Boston, MA, USA: Beacon.

Jirásek, I. (2011). Pilgrimage as a Form of Physical and Movement Spirituality. In J. Parry., Nesti, M. and N.J. Watson (eds.), Theology, Ethics and Transcendence in Sports (pp. 223-232). New York: Routledge.

Johnston, R.K. (1983). The Christian at Play. Grand Rapids, MI, USA: William B. Eerdmans Publishing Company.

L’Arche International (2013). Home Page. Retrieved 15 August, 2013, from http://www.larche.org/

Lixey, K.., Hübenthal, C., Mieth, D. \& Müller, N. (2012). Sport and Christianity: A Sign 
of the Times in the Light of Faith. Washington, DC, USA: Catholic University of America Press.

Luo, J. (2010). ‘Betwixt and Between’: Reflections on the Ritual aspects of the Opening and Closing Ceremonies of the Beijing Olympics. Sport in Society, (13)5, 771783.

Mathisen, J. (2005). Sport. In Helen R. Abaugh. (ed.) Handbook of Religion and Social Institutions (pp. 279-299). New York: Springer.

Moltmann, J. (1972). Theology of Play. New York: Harper.

Nouwen, H. (1997). Adam: God's Beloved. Maryknoll, New York, USA: Orbis.

Null, A. (2004). Real Joy: Freedom to be your Best, Ulm, Germany: Holzerlingen Hanssler.

O’Keefe, C. (1994/2006). Leisure at L 'Arche: Communities of Faith for Persons with Developmental Disabilities. In Heintzman, P., \& Van Andel, G. (eds.), Christianity and Leisure (pp. 116-124). IA: Dordt College Press.

Overman, S.J. (2011). The Protestant Work Ethic and the Spirit of Sport: How Calvinism and Capitalism Shaped American Games. Macon, GA, USA: Mercer University Press.

Patterson, I. \& Pegg, S. (2009). Serious Leisure and People with Intellectual Disabilities: Benefits and Opportunities. Leisure Studies, 28(4), 387-402.

Pieper, J. (1965). In Tune with the World: A Theory of Festivity. New York: Harcourt, Brace and World.

Pieper, J. (1948/1998). Leisure: The Basis of Culture. IN, USA: St. Augustine Press. 
Reinders, H. (2010). The Paradox of Disability: Responses to Jean Vanier and L'Arche Communities from Theology and Sciences. Grand Rapids, MI, USA: William B Eerdmans Publishing Co.

Reimer, K. (2009). Living L'Arche: Stories of Compassion, Love and Disability. London: Continum.

Savage, S. B. (2000). Through Dance: Fully Human, Fully Alive. In J. Begbie (ed.), Beholding the Glory: Incarnation through the Arts (pp. 64-82). UK: Darton, Longman and Todd.

Shafer, M.R. (2012). A Christian Theology of Sport and the Ethics of Doping. PhD. Thesis, University of Durham, UK. Retrieved 3 May, 2013, from http://etheses.dur.ac.uk/6398/1/A_Christian_Theology_of_Sport_and the_Ethics of_Doping1.pdf

Shriver, T. (2014). Triumph from Anguish: The Inspiration of the Special Olympics. Journal of Religion Disability and Health, 18(1), pp. tbc.

Siperstein, G.N., Kersh, J., \& Bardon, J.N. (2007). A New Generation of Research in Intellectual Disabilities: Charting the Course (Report), A Special Olympics Working Conference, Miami, FL, December 6-7, 2007. Retrieved 17 September, 2010, from $\quad$ http://media.specialolympics.org/soi/files/healthyathletes/2007\%20Research\%20Agenda\%20Miami.pdf

Special Olympics (2013) Mission Statement. Retrieved 17 July, 2013, from http://www.specialolympics.org/mission.aspx

Spink, K. (2006). The Miracle, The Message, The Story. London: Dartan, Longman and 
Todd.

Swinton, J. (2012). From Inclusion to Belonging: A Practical Theology of Community, Disability and Humanness. Journal of Religion, Disability and Health, 16(2), $172-190$.

Thoennes, E.K. (2008). Created to Play: Thoughts on Play, Sport and Christian Life. In D. II. Deardorff and D.J. White (eds.), The Image of God in the Human Body: Essays on Christianity and Sports (pp. 79-100). Lampeter, Wales: The Edwin Mellen Press.

UN (2006). Participation in Cultural Life, Recreation, Leisure and Sport. Retrieved 26 July, 2013, from http://www.un.org/disabilities/convention/conventionfull.shtml

Vanier, J. (2004). Drawn into the Mystery of Jesus Through The Gospel of John. London: Darton, Longman, and Todd.

Vanier, J. (1998). Becoming Human. Toronto, ON, Canada: House of Anansi Press. Vanier, J. (1995). The Heart of L'Arche. Toronto, Canada: Novalis Publications.

Walford, G.A. (2009). Sport Humor: A Detailed Analysis. Frederick, MD, USA: PublishAmerica.

Watson, N.J. (2013). Special Olympians as a ‘Prophetic Sign’ to the Modern Sporting Babel, in N.J. Watson and A. Parker. (eds.), Sports and Christianity: Historical and Contemporary Perspectives. London: Routledge: 167-206.

Watson, N.J. (2012). Sport, Disability and the Olympics: An Exploration of the Status and Prophetic Role of the Special Olympic Movement in Light of the London 2012 Olympic and Paralympic Games. The Bible in Transmission (Journal of the 
Bible Society), Spring, 14-16. Retrieved 4 December, 2013, from http://www.biblesociety.org.uk/uploads/content/bible_in_transmission/files/2012_ spring/BiT_Spring_2012_Watson.pdf

Watson, N.J. (2007). Muscular Christianity in the Modern Age: "Winning for Christ” or “Playing for Glory”? In J. Parry., S. Robinson., N.J. Watson \& M.S. Nesti, Sport and Spirituality: An Introduction (pp. 80-94). London: Routledge.

Watson, N.J. \& Parker, A. (2013), Sports and Christianity: Mapping the Field. In N.J. Watson \& A. Parker (eds.), Sports and Christianity: Historical and Contemporary Perspectives (foreword by Michael Novak) (pp. 9-111). London: Routledge.

Watson, N.J. \& Parker, A. (2012). Christianity, Disability and Sport: A Case Study of the Role of Long-Distance Running in the Life of a Father and a Son who is Congenitally Blind and has Profound Intellectual Disabilities. Practical Theology, (5)2, 191-210.

Weber, M. (1958). The Protestant Ethic and the Spirit of Capitalism (trans. Talcott Parsons). New York: Free Press.

Wellard, I. (2014). Sport, Fun and Enjoyment: An Embodied Approach. London: Routledge.

Whitney-Brown, C. (2008). Jean Vanier: Essential Writings (Introduction by Carolyn Whitney-Brown). Maryknoll, New York, USA: Orbis Books. 
Yong, A. (2014). Running the (Special) Race: What Would St. Paul say about Sports in the Late Modern World. Journal of Religion, Disability and Health, 18(2), pp. tbc. 